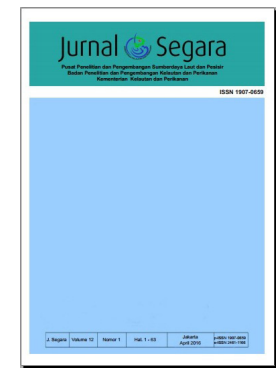

JURNAL SEGARA

http://ejournal-balitbang.kkp.go.id/index.php/segara

ISSN : 1907-0659

e-ISSN : 2461-1166

Nomor Akreditasi: 766/AU3/P2MI-LIPI/10/2016

\title{
ABRASI DAN AKRESI BERDASARKAN LONGSHORE SEDIMENT TRANSPORT SERTA PERUBAHAN GARIS PANTAI: STUDI KASUS PANTAI PULAU CEMARA BESAR, KARIMUNJAWA
}

\author{
ABRASION AND ACCRETION BASED ON LONGSHORE SEDIMENT TRANSPORT AND \\ SHORELINE CHANGE CALCULATIONS: A CASE STUDY IN CEMARA BESAR ISLAND, \\ KARIMUNJAWA
}

\author{
Yulius1), Nur Kholik Kurniana Putra²), Baskoro Rochaddi'2), Muhammad Ramdhan'1) \\ 1) Pusat Riset Kelautan, Badan Riset dan Sumber Daya Manusia Kelautan dan Perikanan, KKP \\ 1)Departemen Oseanografi, Fakultas Perikanan dan IImu Kelautan, Universitas Diponegoro
}

Diterima: 5 Agustus 2020; Diterima Setelah Perbaikan: 10 Desember 2020; Disetujui Terbit: 20 Desember 2020

\begin{abstract}
ABSTRAK
Pulau Cemara Besar merupakan pulau yang direncanakan menjadi kawasan ekowisata bahari di Kepulauan Karimunjawa menurut Kementerian Kelautan dan Perikanan. Oleh karenanya, analisis geologi dan oseanografi pesisir diperlukan untuk pengambilan keputusan. Penelitian ini dilaksanakan untuk mengkaji transport sedimen sejajar pantai dan garis pantai yang diakibatkannya. Perubahan garis pantai diperoleh dari analisis DSAS menggunakan citra Sentinel 2A selama tahun 2016 2020 dan tracking garis pantai menggunakan GPS geodetik pada Maret 2020. Parameter inputan transport sedimen sejajar pantai diperoleh dari data model reanalysis ERA-5 yang selanjutnya dilakukan peramalan gelombang dengan metode SMB dan analisis gelombang representatif. Ukuran butir sedimen diambil di sepanjang pantai sebanyak 14 titik dan dilakukan analisis granulometri untuk mengetahui besar d50 sedimen. Transport sedimen sejajar pantai diprediksi menggunakan persamaan empiris dari CERC, Walton Jr, dan Kamphuis. Berdasarkan hasil penelitian didapatkan bahwa transport sedimen sejajar pantai menyebabkan abrasi di ekor pulau sebelah timur dan pangkal pulau selatan serta akresi di ekor pulau utara dan pangkal pulau sebelah timur yang dicirikan dengan adanya perubahan garis pantai di lokasi tersebut. Analisis regresi linier menunjukan laju LST di sepanjang pantai berpengaruh sebesar $13,83 \%$ terhadap perubahan garis pantai.
\end{abstract}

Kata Kunci: Abrasi, akresi, transport sedimen, perubahan garis pantai.

\begin{abstract}
Cemara Besar Island is located in Karimunjawa Islands. This island was planned as a marine ecotourism area by the Ministry of Marine Affairs and Fisheries. The geological and oceanographic analysis was needed for spatial decision making. This research was conducted to analyze the longshore sediment transport and the shoreline change caused by it. Shoreline change was obtained from Sentinel 2A images from 2016 to 2020 and observation shoreline using the geodetic Global Positioning System (GPS) in March 2020. Shoreline data was analyzed using the Digital Shoreline Analysis System (DSAS). Longshore sediment transport was calculated from ERA-5 reanalysis model data. Then the wave hindcasting was done using the SMB method and representative wave analysis. The sediment grains size was taken along the coast by 14 points and a granulometric analysis was carried to determine the $d 50$ sediment size. LST was predicted using empirical equations from CERC, Walton Jr., and Kamphuis. LST causes abrasion on the eastern tail and base of the southern island. While accretion occurs at the tail of the north island and the base of the eastern island. Both were indicated by shoreline change at these locations. Linear regression analysis showed that the LST rate had an effect of $13.83 \%$ on shoreline changes.
\end{abstract}

Keyword: Abrasion, accretion, LST, shoreline change.

Corresponding author:

JI. Pasir Putih I Ancol Timur, Jakarta Utara 14430. Email: nurkholikurnianaputra@gmail.com 


\section{PENDAHULUAN}

Pantai merupakan ekosistem dengan dinamika yang kompleks. Bila dilihat dari interaksinya, pantai menjadi zona interaksi antara daratan, dan laut. (Aedla et al., 2015). Interaksi tersebut menyebabkan proses alam dari laut ke darat maupun sebaliknya yang berlangsung secara terus menerus. Proses alam yang terjadi diantaranya berupa abrasi, akresi, pencemaran lingkungan, serta bencana pesisir dan laut. Selain itu, pengaruh aktifitas manusia seperti proses pembangunan dan pengelolaan wilayah pesisir juga ikut berperan (Beatley et al., 2002). Selaras dengan hal tersebut, Guariglia et al. (2006) menyatakan bahwa profil pantai dapat berubah secara cepat maupun lambat bergantung pada topografi pantai, proses hidro-oseanografi, kondisi iklim, vegetasi pesisir, dan transport sedimen.

Garis pantai secara sederhana didefinisikan sebagai pertemuan antara darat dan laut (Horikawa, 1988; Chen \& Chang, 2009). Ditinjau dari sudut pandang teori perubahan garis pantai akibat dinamika alam dan praktik di lapangan, Boak and Turner (2005) mengklasifikasikan indikator perubahan garis pantai dari hasil penelitiannya dalam 2 kategori. Kategori pertama, didasarkan pada visualisasi kenampakan pantai yang terlihat. Sedangkan, kategori kedua yakni garis pantai yang terikat dengan datum elevasi vertikal (pasang surut).

Garis pantai secara berkelanjutan dapat berubah pada jangka waktu tertentu akibat dari variasi pantai, hasil dari transport sedimen (on-offshore dan longshore) dan akibat dari dinamika muka air laut, baik gelombang maupun pasang surut (Alesheikh et al., 2007; Chen \& Chang, 2009). Proses yang terjadi di sepanjang pantai yang diakibatkan oleh berbagai faktor salah satunya penjalaran gelombang dikenal dengan proses litoral. Triatmodjo (1999) mengklasifikasikan proses litoral menjadi dua jenis, yaitu onshore-offshore transport, merupakan transport sedimen yang bergerak menuju dan meninggalkan pantai dengan arah tegak lurus pantai; dan longshore sediment transport (LST), merupakan transport sedimen yang bergerak sejajar garis pantai dengan arah bergantung dari arah arus sejajar pantai.

Pulau Cemara Besar merupakan salah satu pulau yang terletak di Kepulauan Karimunjawa, Indonesia. Lokasi penelitian ini secara geografis terletak di $110^{\circ} 22^{\prime} 20^{\prime \prime B T} 5^{\circ} 48^{\prime} 11.5^{\prime \prime}$ "LS - $110^{\circ} 22^{\prime} 38.6^{\prime \prime} B T$ $5^{\circ} 48^{\prime} 30$ 'LS. Sebagai pulau yang terletak sekitar $50 \mathrm{mil}$ laut di lepas pantai utara Pulau Jawa menjadikan pulau ini berinteraksi langsung dengan Laut Jawa. Cemara Besar termasuk pulau kecil yang dikelilingi karang (fringing reef) dengan daya tarik wisata yang tinggi (Yuliana, 2017). Dalam Rencana Zonasi Wilayah
Pesisir dan Pulau Pulau Kecil (RZWP-3-K) Kementerian Kelautan dan Perikanan Republik Indonesia, menjelaskan bahwa Pulau Cemara Besar akan dikembangkan sebagai kawasan ekowisata bahari, yaitu kawasan wisata alam dengan tetap mempertahankan kondisi dan keberlanjutan ekosistem alami. Dengan demikian daya tarik utama ekowisata yakni dari kenampakan dan fenomena alamnya (Yulius et al., 2018).

Perencanaan dan pengembangan kawasan wisata pesisir dan laut sebagai ekowisata bahari harus mempertimbangkan daya dukung lingkungan (Yulius et al., 2018). Daya dukung lingkungan berupa komponen kondisi geografis, meliputi kondisi geologi, topografi, oseanografi, dan iklim. Salah satu komponen dalam kondisi tersebut adalah garis pantai (Umardiono, 2011).

Salah satu metode yang efektif untuk mengukur perubahan garis pantai adalah penginderaan jauh dan sistem informasi geografi (SIG) (Aedla et al., 2015). Dengan menggunakan Digital Shoreline Analysis System (DSAS), Ramdhan et al. (2020) mendapatkan segmen-segmen khusus yang mencirikan fenomena abrasi dan akresi di Pulau Cemara Besar. Fenomena ini memberikan dampak langsung untuk garis pantai dan dampak tidak langsung untuk pemanfaatan ruang pesisir dan laut (Bird, 2011; Goswami et al., 2019).

Pada penelitian ini akan dikaji pengaruh transport sedimen di sepanjang pantai, terutama longshore sediment transport (LST) sebagai penyebab abrasi dan akresi serta berubahnya garis pantai di sepanjang Pulau Cemara Besar. Pendekatan yang digunakan yakni melalui beberapa persamaan empiris untuk melihat kondisi transport sedimen. Sedangkan perubahan garis pantai dideteksi dengan pendekatan spasial melaui perbandingan garis pantai dalam kurun waktu yang berbeda.

\section{METODE PENELITIAN}

\section{Pengumpulan Data Garis Pantai}

Data garis pantai diperoleh dari deliniasi citra sentinel 2A dan pengukuran langsung di lapangan. Citra yang digunakan adalah citra tahun 2016 - 2020 pada perekaman musim barat. Citra dikoreksi radiometrik dan geometrik dengan bantuan tools rayleigh correction pada aplikasi SNAPDesktop serta dilakukan koreksi terhadap TOA Reflectance, sehingga, citra hasil koreksi akan mendekati kebenaran sesuai di lapangan. Untuk memperoleh perbedaan rona antara daratan dan perairan citra hasil koreksi dilakukan filtering terhadap band citra dengan metode NDWI menurut McFeeters (1996), secara matematis ditunjukkan sebagai berikut : 
$N D W I=\frac{\text { Green }-N I R}{\text { Green }+N I R}$

Deliniasi garis pantai terhadap citra sentinel menggunakan metode digitasi on-screen (Chand, 2010). Metode tersebut digunakan dengan mempertimbangkan lokasi penelitian yang memiliki cakupan kecil.

Garis pantai hasil deliniasi dikoreksi menggunakan data pasang surut. Data pasang surut diperoleh dari stasiun pengamatan pasang surut Karimujawa-Jateng dengan nomor StationID: 0137KRJW01 milik Badan Informasi Geospasial. Datum referensi yang digunakan adalah level air MSL Maret 2020. Elevasi MSL diperoleh dengan analisis komponen pasang surut berdasarkan metode least square. Hal ini dimaksudkan untuk memastikan bahwa perubahan garis pantai yang dihitung dalam validasi data tidak disebabkan oleh variasi pasang surut. Koreksi pasang surut dilakukan mengacu pada teori segitiga siku-siku (Wicaksono et al., 2018)

Garis pantai hasil survey lapangan diperoleh dengan metode tracking menggunakan GPS Geodetik $\mathrm{CHCNav}$ tipe i50 dengan ketelitian horizontal $1,5 \mathrm{~cm}$ dan vertikal 2,3 cm. Menurut (Guariglia et al., 2006) tujuan survey garis pantai menggunakan GPS antara lain: memetakan garis pantai terbaru, memverifikasi keakuratan citra, dan membuat jaringan referensi survey berikutnya. Survey dilakukan dengan mempertimbangkan pasang surut. Panjang garis pantai yang akan di survey sepanjang 1528 meter.

\section{Model Perubahan Garis Pantai}

Perubahan garis pantai dideteksi dengan batuan model Digital Shoreline Analysis System (DSAS). DSAS menggunakan titik base sebagai acuan pengukuran, dimana titik dihasilkan dari perpotongan antara garis transek dengan garis-garis pantai berdasarkan waktu (Esmail et al., 2019; Salmon et al., 2019).

Pada penelitian ini digunakan metode perhitungan Linear Regression Rate (LRR) untuk menunjukan konsistensi perubahan garis pantai berdasarkan nilai regresi jarak garis pantai terhadap baseline dan waktu garis pantai, End Point Rate (EPR) menunjukan laju perubahan garis pantai dalam meter/tahun, dan Net Shoreline Movement (NSM) menunjukan jarak perubahan garis pantai terlama ke terbaru dalam meter (Himmelstoss et al., 2018). Penentuan daerah abrasi ditentukan jika LRR dam NSM $<0$ serta daerah akresi jika LRR, dan NSM > 0 .

\section{Kelerengan Pantai}

Pengambilan data kelerengan pantai terdiri dari
14 stasiun seperti disajikan pada Gambar 1. Penentuan stasiun berdasarkan purposive sampling dengan pertimbangan kesamaan lokasi yang mengalami abrasi dan akresi.

Pengambilan data dilakukan dengan bantuan alat GPS Geodetik $\mathrm{CHCNav}$ tipe i50 yang mampu merekam ketinggian hingga ketelitian $0,02 \mathrm{~cm}$. Pada setiap stasiun, kelerengan diukur setiap $3 \pm 0,02 \mathrm{~m} \times 2$ transek. Sehingga diperoleh titik perekaman dengan nilai ketinggian masing-masing dan diketahui selisih tinggi setiap titiknya. Setiap stasiun diperoleh 2 segmen sepanjang $6 \pm 0,02 \mathrm{~m}$. Data setiap segmen ini diratarata, sehingga diperoleh kelerengan pantai pada setiap stasiun. Kelerengan pantai diperlukan sebagai inputan menghitung LST.

\section{Ukuran Butir Sedimen}

Pengambilan sampel sedimen dasar dilakukan di sepanjang pantai Pulau Cemara Besar berdasarkan purposive sampling. Penentuan titik sampling ini berdasarkan pengamatan awal garis pantai melalui google earth pro dan melihat lokasi yang diduga mengalami abrasi dan akresi. Jumlah stasiun berjumlah 14 stasiun seperti disajikan pada Gambar 1.

Ukuran butir sedimen diperoleh dari hasil analisis granulometri sampel sedimen dasar. Sampel sedimen hasil pengambilan di lapangan, selanjutnya akan dilakukan analisis granulometri. Sieve shaker yang akan digunakan memiliki 5 ayakan dengan ukuran 2 $\mathrm{mm} ; 0,5 \mathrm{~mm} ; 0,3 \mathrm{~mm} ; 0,125 \mathrm{~mm}$; dan 0,0625 mm. Bila terdapat sisa hasil ayakan (ukuran $<0,0625 \mathrm{~mm}$ ) maka dilakukan penentuan ukuran butir menggunakan metode pipetting. Ukuran butir yang akan diperoleh menggunakan metode pipetting yakni $0,0312 \mathrm{~mm}$; $0,0156 \mathrm{~mm} ; 0,0078 \mathrm{~mm}$; dan $0,0039 \mathrm{~mm}$. Hasil penentuan ukuran butir sedimen selanjutnya di plot dalam sieve graph dan diperoleh besar ukuran d50 dari sampel sedimen. Selanjutnya ukuran butir akan diklasifikasikan berdasarkan klasifikasi skala Wentworth (CEM, 2002).

\section{Prediksi Data Gelombang}

Data gelombang berupa tinggi gelombang signifikan (Hs meter) dan periode gelombang signifikan (Ts detik) didapatkan dengan peramalan gelombang menggunakan metode SMB (Svedrum Munk Bretschneider). Data input berupa data angin yang diperoleh dari https://climate.copernicus.eu/climatereanalysis penyedia data angin hasil model reanalysis untuk tahun 2015-2019. Tahapan peramalan gelombang terdiri dari filterisasi data angin, penentuan panjang fetch efektif, dan perhitungan periode dan tinggi gelombang laut (CERC, 1984).

Ketinggian angin berhembus dikoreksi menjadi ketinggian 10 meter (Resio et al., 2003) dengan 


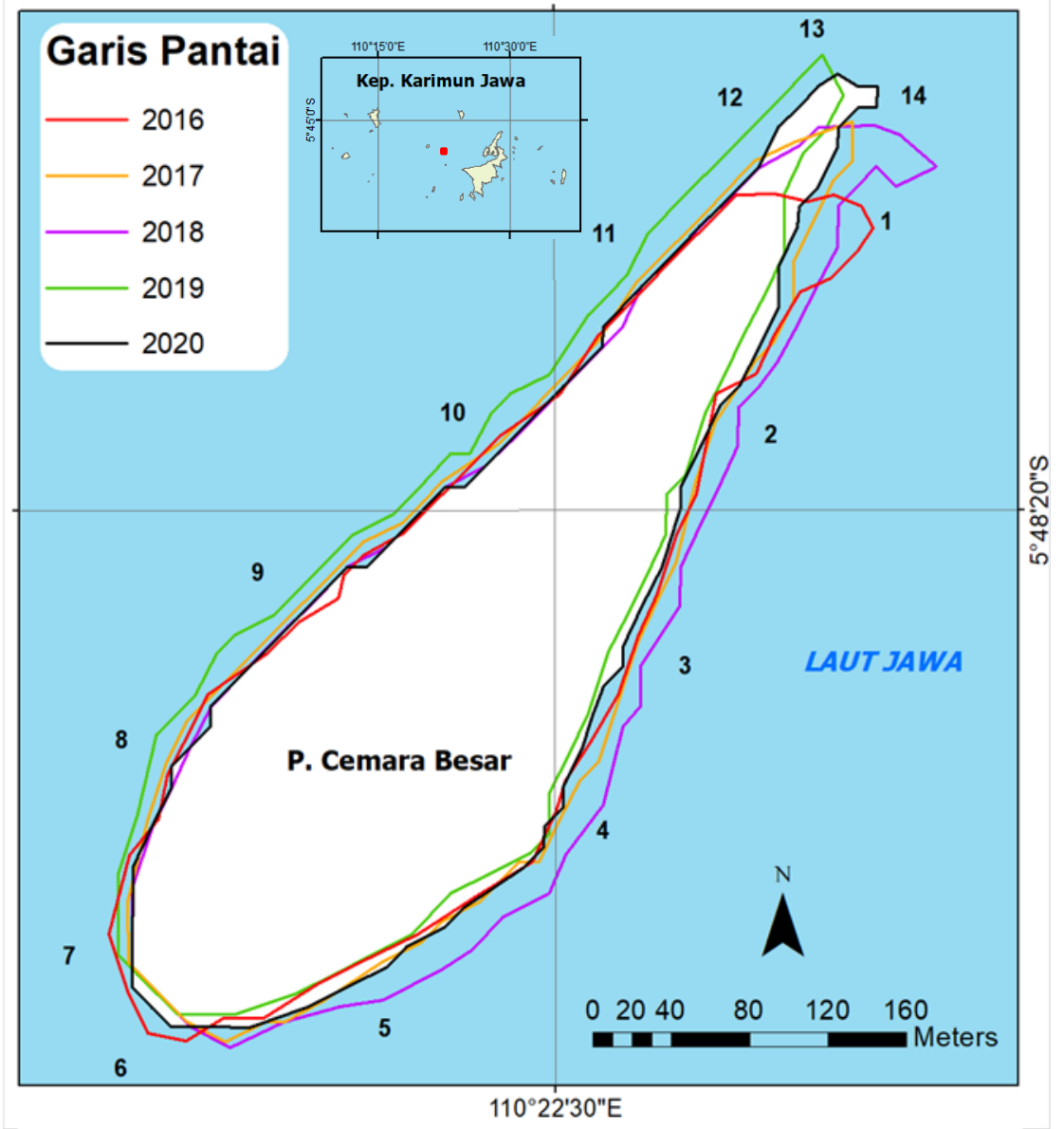

Gambar 1. Garis pantai Pulau Cemara Besar 2016-2020.

persamaan berikut :

$$
U_{z}=U_{10}\left(\frac{Z}{10}\right)^{\alpha}
$$

dimana,

Uz : kecepatan angin diukur dari ketinggain lokasi stasiun $(\mathrm{m} / \mathrm{s})$,

$U_{10}$ : kecepatan angin pada ketinggian 10 meter (m.s), $z$ : adalah ketinggian dari permukaan $(\mathrm{m})$, dan : index power sebesar 0,12.

Penentuan panjang didasarkan pada arah dominan angin yang kemudian dihitung menggunakan persamaan berikut:

$$
X=\frac{\sum_{i=1}^{15} X i \cos \alpha_{i}}{\sum_{i=1}^{15} \cos \alpha_{i}}
$$

dimana,

$X$ : panjang fetch efektif $(\mathrm{m})$,

$\alpha$ : sudut antara garis fetch sebesar $6^{\circ}$.

Nilai tinggi gelombang $(\mathrm{H})$ dan periode gelombang $(T)$ dapat ditentukan bila dalam kondisi fully developed sea dan fetch-limited condition. Pada kondisi fully developed sea persamaan yang digunakan adalah sebagai berikut:

$$
\begin{aligned}
\frac{g H_{m}}{U_{A}^{2}} & =2,433 \times 10^{-1} \\
\frac{g T_{m}}{U_{A}} & =8,134
\end{aligned}
$$

Sedangkan kondisi fetch-limited condition terjadi bila duration limited lebih besar dari periode minimum. Maka persamaan yang digunakan untuk mendapatkan $\mathrm{Hm}$ ditulis dalam (CERC, 1984) :

$$
\frac{g H_{m}}{U_{A}^{2}}=1,6 \times 10^{-3}\left(\frac{g F}{U_{A}^{2}}\right)^{\frac{1}{2}}
$$

$$
\frac{g H_{m}}{U_{A}^{2}}=1,6 \times 10^{-3}\left(\frac{g F}{U_{A}^{2}}\right)^{\frac{1}{2}}
$$

Dimana $H m$ : tinggi gelombang model $(m), T m$ : periode gelombang model (s), $U_{A}$ : kecepatan angin 
terkoreksi $(\mathrm{m} / \mathrm{s}), F$ : panjang fetch efektif $(m)$, dan $g$ : percepatan gravitasi $\left(9,81 \mathrm{~m} / \mathrm{s}^{2}\right)$.

Hasil perolehan data $\mathrm{Hm}$ dan $\mathrm{Tm}$ digunakan untuk menentukan tinggi gelombang signifikan $(H s)$ dan periode gelombang signifikan (Ts). Metode yang digunakan dengan statistik, yakni menghitung 33,3\% data tertinggi dari seluruh data untuk $\mathrm{Hm}$ dan $\mathrm{Tm}$.

Data gelombang $H s$ dan Ts menjadi input menghitung parameter gelombang pecah menggunakan metode gelombang representatif (Triatmodjo, 1999). Hasil perhitungan tersebut berupa tinggi gelombang pecah $(H b$, meter), kedalaman gelombang pecah ( $d b$ meter), dan sudut datang gelombang pecah $\left(\alpha b,{ }^{\circ}\right)$. Data tersebut digunakan untuk menghitung LST.

\section{Longshore Sediment Transport}

Besaran LST diperoleh dari perhitungan beberapa persamaan empiris dengan memasukkan komponen-komponennya. LST terjadi sepanjang tahun dengan arah yang berbeda, baik musim barat maupun musim timur. Untuk memperoleh nilai laju LST yang melewati suatu titik di pantai dalam kurun waktu tertentu, LST masing-masing musim dihitung berdasarkan persamaan LST net $(Q n)$ sebagai berikut:

$Q n=Q r t-Q / t$

dimana Qrt pada saat musim barat dan Qlt saat musim timur. Sehingga $Q n$ dapat bernilai positif jika Qrt $>$ Q/t dan bernilai negatif jika Qrt < QIt (CEM, 2002).

\section{Persamaan CERC}

LST menurut CERC (1984) dihitung berdasarkan energi yang disebabkan oleh gelombang yang menjalar ke pantai. Dengan demikian memungkinkan analisis transport sedimen sejajar pantai dilakukan dengan melihat penjalaran gelombang dari arah yang bervariasi. LST didekati dengan menghitung energy flux gelombang diberikan dalam persamaan berikut:

$$
P_{1}=\left(E C_{g}\right)_{b} \sin \alpha_{b} \cos \alpha_{b}
$$

dimana Eb merupakan energi gelombang pada gelombang pecah diberikan dalam persamaan berikut:

$$
E_{b}=\frac{\rho g H_{b}^{2}}{8}
$$

Dan $C_{g b}$ merupakan kecepatan grup gelombang pada gelombang pecah diberikan dalam persamaan berikut:

$$
C_{g b}=\sqrt{g d_{b}}
$$

Dimana $\alpha_{b}$ adalah sudut datang gelombang pecah $\left(^{\circ}\right), \mathrm{Hb}$ merupakan tinggi gelombang pecah $(\mathrm{m})$, dan $\mathrm{db}$ adalah kedalaman gelombang pecah $(\mathrm{m})$. Sehingga nilai LST diperoleh dengan persamaan berikut :

$$
Q=\frac{K A \rho g H_{b}^{2} T \sin \left(2 \alpha_{b}\right)}{64 \pi}
$$

dimana $Q$ adalah transport sedimen sejajar pantai $\left(\mathrm{m}^{3} /\right.$ tahun), $K$ adalah konstanta empiris,

$$
A=\frac{1}{\left(\rho_{s}-\rho\right) g(1-p)}
$$

dimana $\rho_{s}$ adalah densitas sedimen $\left(\mathrm{kg} / \mathrm{m}^{3}\right), \rho$ adalah densitas air laut $\left(\mathrm{kg} / \mathrm{m}^{3}\right), g$ adalah percepatan gravitasi $\left(\mathrm{m} / \mathrm{s}^{2}\right), p$ adalah faktor porositas $(0,4), T$ adalah periode gelombang (s), dan $\alpha_{b}$ adalah sudut datang gelombang pecah $\left({ }^{\circ}\right)$.

\section{Persamaan Walton Jr dan Bruno}

Persamaan lainnya dikemukakan oleh Walton $\mathrm{Jr}$ \& Bruno (1989) dengan menggunakan tinggi gelombang pecah dan arus sejajar pantai. LST didasarkan pada rumus empiris hasil perbandingan pengukuran sediment trap lapangan dengan hasil komputasi numerik. Sehingga nilai transport sedimen dapat dihitung dengan persamaan berikut:

$$
Q=\frac{K A \rho g H_{b} W V C_{f}}{0,78\left(\frac{5 \pi}{2}\right)\left(\frac{V}{V_{0}}\right)_{L H}}
$$

dimana $V$ adalah rata-rata kecepatan longshore current $(\mathrm{m} / \mathrm{s})$ (Longuet-Higgins, 1970) diberikan dalam persamaan berikut :

$$
V=20,7 m\left(g H_{b}\right)^{1 / 2} \sin \left(2 \alpha_{b}\right)
$$

$W$ adalah lebar surf zone $(\mathrm{m}), C_{f}$ adalah koefisien friksi dengan nilai 0,005 (Shanas \& Kumar, 2014), (V/ Vo) $L_{H}$ adalah teori kecepatan arus sejajar pantai dengan parameter campuran bernilai 0,4 (LonguetHiggins, 1970), dan $\mathrm{m}$ adalah gradien kemiringan lereng.

\section{Persamaan Kamphuis}

Transport sedimen sejajar pantai dapat diperoleh dari kemiringan pantai, periode gelombang, dan ukuran butir sedimen $\left(\mathrm{d}_{50}\right)$ yang dikembangkan oleh (Kamphuis, 
2003) berdasarkan eksperimen laboratorium dan data lapangan. Persamaan transport sedimen diekspresikan dalam persamaan berikut :

$$
Q=\left[\frac{2.27 H_{b}^{2} T_{P}^{1.5} m^{0.75} d_{50}^{-0.25} \sin \left(\alpha_{b}\right)}{\left(\rho_{s}-\rho\right) g(1-\rho)}\right]
$$

Dimana, $T p$ adalah periode gelombang puncak (s), dan $d_{50}$ adalah median ukuran butir sedimen ( $\mathrm{mm}$ ).

\section{HASIL DAN PEMBAHASAN}

\section{Perubahan Garis Pantai}

Hasil uji akurasi geometri diperoleh nilai RMSE sebesar 0.04 dengan nilai kepercayaan 96\%. Sehingga garis pantai hasil intepretasi dari indeks air NDWI dapat digunakan untuk analisis perubahan garis pantai. Kondisi tersebut sesuai dengan syarat akurasi geometri menurut Wicaksono \& Wicaksono (2019). Garis pantai dari 2016 - 2020 ditunjukkan pada Gambar 1. Di sepanjang pantai Pulau Cemara Besar dibagi menjadi 14 segmen. Segmen 1-4 berada di sebelah timur pulau, segmen 5-7 berada di selatan yang kemudian disebut pangkal pulau, 8-11 di sebelah barat pulau, dan segmen 12-14 di utara pulau yang kemudian disebut ekor pulau.
Garis pantai pada rentang waktu tersebut terlihat dinamis di sepanjang pantai. Mengingat Cemara Besar merupakan pulau hasil endapan sedimen maka dinamika garis pantai sangat dipengaruhi proses litoral dan kegiatan masyarakat yang berkunjung ke pulau. Dinamika sangat tinggi nampak pada ekor pulau. Secara umum garis pantai pada ekor pulau sejak 2016 2020 bergerak ke utara. Sehingga terdapat area abrasi dan akresi di lokasi tersebut.

Pada sisi timur secara umum terjadi pergerakan ke arah laut dari 2016 hingga 2018 dan kembali menyusut hingga 2020. Sedangkan pada sisi barat dinamika yang terjadi cenderung tetap, dan tampak garis pantai menuju laut pada tahun 2019. Sedangkan pada pangkal pulau tampak ada trend abrasi terutama di segmen 7 yang ditandai dengan pergerakan garis pantai menuju darat.

Abrasi dan akresi terjadi di sepanjang pantai ditunjukkan pada Gambar 2. Luasan abrasi sebesar 0,41 ha dan akresi sebesar 0,33 ha. Abrasi terjadi di ekor pulau sebelah timur, sepanjang sisi timur, pangkal hingga sebagian sisi barat, dan sebagian sisi barat pulau. Sedangkan akresi terjadi di ekor pulau dengan bentuk yang memanjang ke utara, pangkal pulau sisi timur, dan sebagian kecil di sisi barat dan timur pulau.

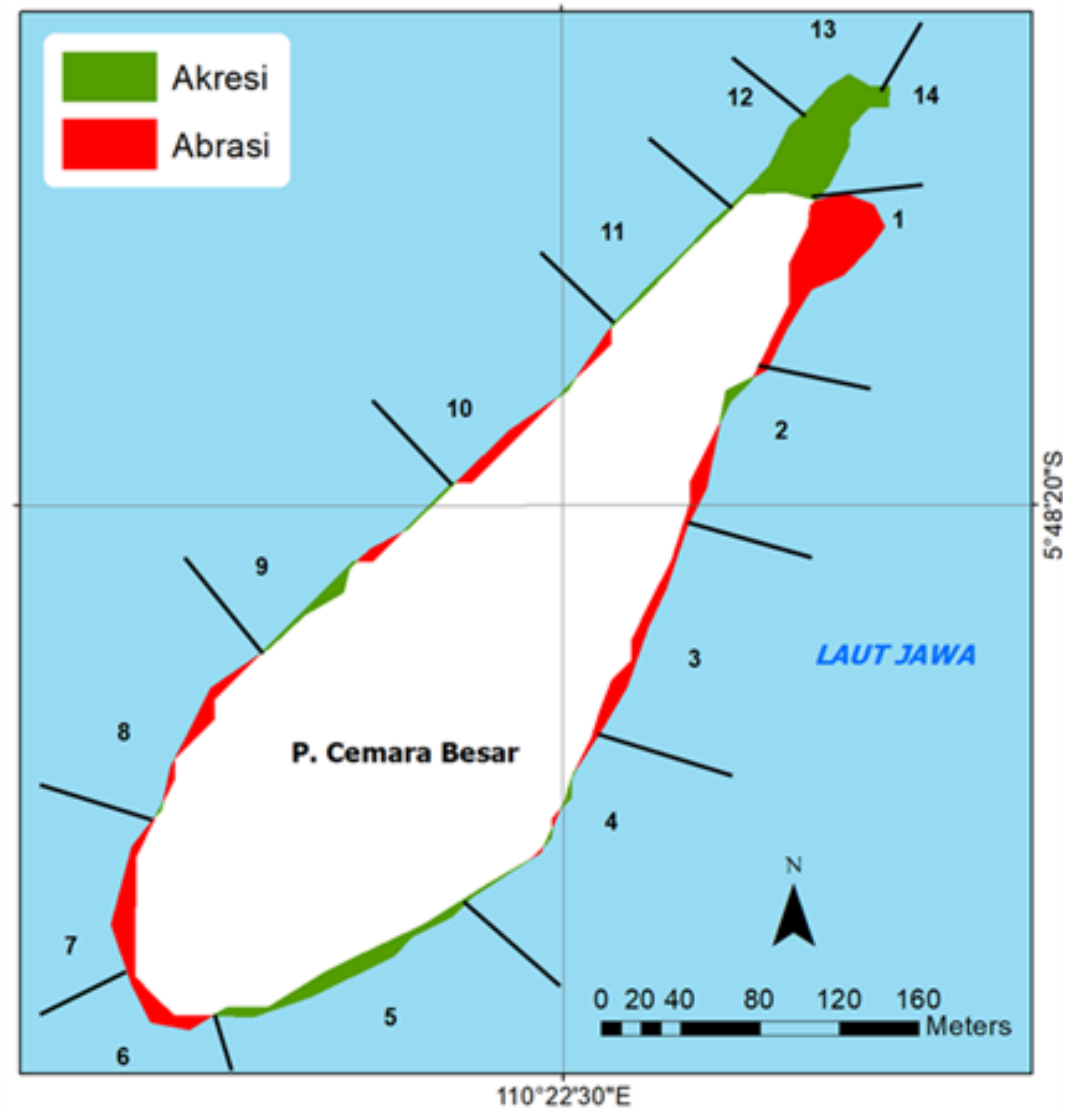

Gambar 2. Luasan Abrasi Akresi Cemara Besar. 
Hasil model DSAS ditampilkan secara mendatar berdasarkan segmen dengan menggunakan metode EPR dan LRR, seperti pada Gambar 3. Hasil menunjukkan bahwa terdapat perbedaan hasil antara metode EPR dan LRR. Metode EPR menghitung laju perubahan garis pantai berdasarkan jarak antara garis pantai terlama dan terbaru pada rentang waktu tersebut. Sedangkan metode LRR menghitung nilai regresi linier antara posisi garis pantai setiap tahun. Dengan demikian EPR menunjukan laju perubahan garis pantai dan LRR menunjukkan kecenderungan garis pantai bergerak.

\section{Karakteristik Sedimen dan Kelerengan Pantai}

Ukuran butir di sepanjang pantai Cemara Besar ditunjukan beradasarkan distribusi percentile ke-50 dinyatakan dalam ukuran butir $d_{50}$. Berdasarkan ukuran tersebut sedimen dasar di pantai Pulau Cemara Besar berjenis pasir dengan ukuran yang bervariasi dengan mayoritas berukuran pasir kasar. Distribusi ukuran sedimen dasar di pantai timur hingga pangkal pulau berukuran pasir kasar. Sedangkan di pantai barat hingga ekor pulau berukuran pasir sedang.

Kelerengan pantai (slope) ditunjukkan berdasarkan klasifikasi (Yulianda, 2007) yang menunjukkan tipe pantai berdasarkan kesuaian terhadap kegiatan wisata pantai. Hasil menunjukan bahwa sepanjang pantai Cemara Besar cocok dijadikan wisata pantai dikarenakan bertipe pantai datar. Pada pulau ini hanya 3 lokasi yang memiliki tipe landai yakni pada stasiun 5, 11, dan 13. Dengan demikian, slope tertinggi terletak di stasiun 11 sebesar $14,52^{\circ}$ dan terendah pada stasiun 14 sebesar $1,07^{\circ}$.

\section{Karakteristik Gelombang}

Hasil peramalan gelombang diperoleh tinggi gelombang signifikan ( $\mathrm{Hs}$ ) dan periode gelombang signifikan (Ts) musim barat sebesar 1,21 m dan 4,69 s, sedangkan Hs dan Ts musim timur sebesar 0,77 m dan $4,33 \mathrm{~s}$. Hasil peramalan dilakukan validasi dengan data lapangan dengan metode RMSE diperoleh nilai nilai error 0,19 untuk Hs dan 0,26 untuk Ts. Berdasarkan Willmott \& Matsuura (2005), semakin rendah nilai bias/ error maka semakin tinggi keterkaitannya.

Analisis statistik frekuensi angin menunjukkan arah angin dominan di Perairan Karimunjawa. Arah angin dominan pada musim barat berhembus dari arah $247,5^{\circ}$ dan pada musim timur berhembus dari arah $67,5^{\circ}$. Sehingga diperoleh arah penjalaran gelombang pada musim barat ke arah $67,5^{\circ}$ dan musim timur ke arah $247,5^{\circ}$.

Berdasarkan perhitungan gelombang representatif, diperoleh tinggi gelombang pecah $(\mathrm{Hb})$, kedalaman gelombang pecah ( $\mathrm{db}$ ), dan sudut datang gelombang pecah (ab). Pada musim barat sudut datang gelombang pecah cenderung lebih besar di sisi timur pulau. Hal ini diakibatkan oleh gelombang yang mencapai pantai merupakan gelombang hasil refraksi akibat posisi stasiun yang berada di balik pulau dari arah penjalaran gelombang. Dengan demikian tinggi gelombang pecah terbesar $0,52 \mathrm{~m}$ serta sudut datang gelombang pecah sebesar $24,37^{\circ}$ hingga $29,27^{\circ}$. Sedangkan di sisi barat gelombang menjalar ke arah pulau, kemudian pecah di kedalaman 0,99 hingga 1,39 $\mathrm{m}$ dengan tinggi gelombang lebih dari 1,3 meter.

Kondisi yang berbeda pada musim timur yakni sisi timur pulau menjadi pantai yang berhadapan langsung dengan penjalaran gelombang musim timur. Sedangkan pada stasiun lainnya gelombang yang mencapai pantai merupakan gelombang hasil refraksi karena lokasi stasiun berada di balik pulau dari arah penjalaran gelombang di musim timur. Akibatnya tinggi

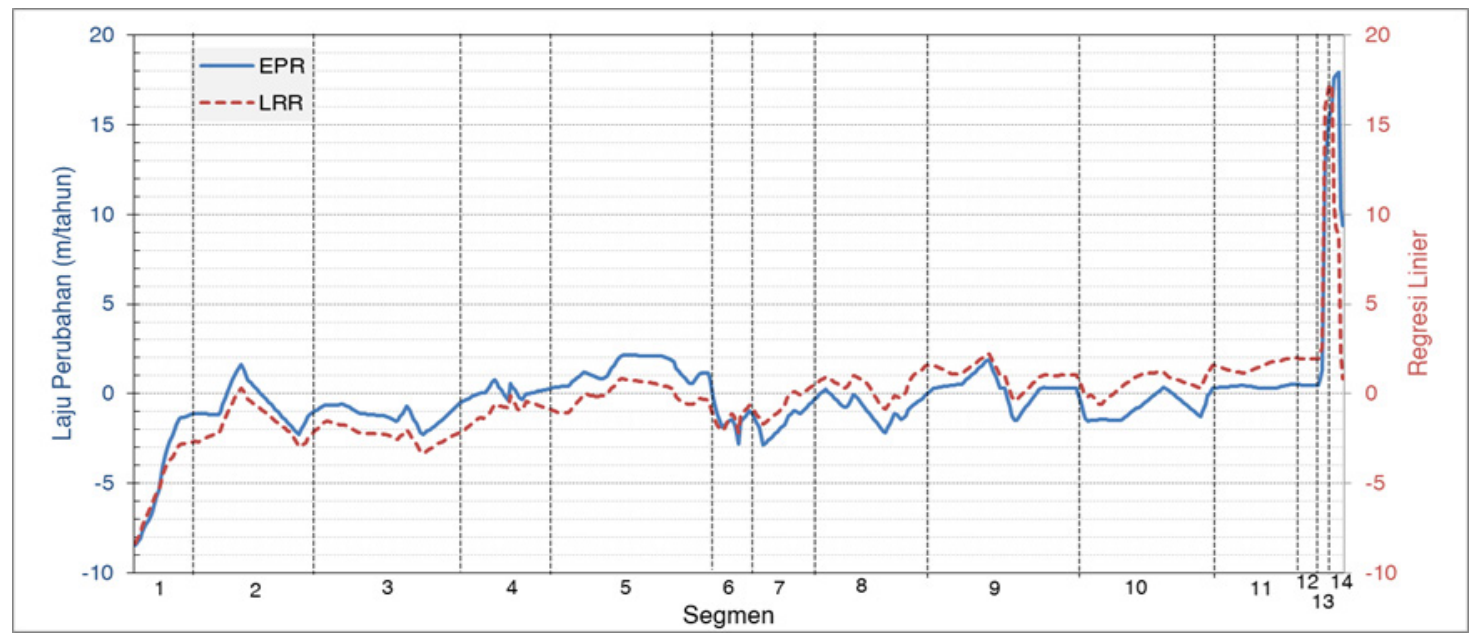

Gambar 3. Hasil model DSAS EPR dan LRR sepanjang pantai

Gambar 3. Hasil model DSAS EPR dan LRR sepanjang pantai. 
gelombang stasiun 6-13 lebih kecil dibandingkan stasiun lainnya. Hasil perhitungan gelombang representatif menghasilkan tinggi gelombang pecah dan kedalaman gelombang pecah relatif lebih rendah dibandingkan musim barat. Sudut datang gelombang pecah tertinggi pada $13,98^{\circ}$ pada stasiun 5 dan nilai terendah sebesar $7,16^{\circ}$ pada stasiun 3 .

\section{Longshore Sediment Transport}

Qn sebagai besaran LST per tahun diperoleh dari selisih $Q$ barat dan $Q$ timur. Bila bernilai positif maka arah LST ke arah LST musim barat, dan negatif ke arah timur. Arah LST ditampilkan pada Gambar 4a sebagai analisis dari arah penjalaran gelombang setiap musim dan perhitungan Qn LST. Nilai Qn terbesar berdasarkan persamaan CERC (persamaan 7) yakni pada stasiun 6 sebesar 439,2 x 1033 m/tahun ke arah musim barat dan $-89,94 \times 10^{3} \mathrm{~m} /$ tahun ke arah musim timur. Pada persamaan Walton $\mathrm{Jr}$ and Bruno (persamaan 8) nilai Qn terbesar ke arah musim barat dan timur adalah $1.604,81 \times 10^{3} \mathrm{~m} /$ tahun pada stasiun 11 dan $-488,25 \times 10^{3} \mathrm{~m} /$ tahun pada stasiun 5 . Sedangkan sesuai persamaan LST milik Kamphuis (persamaan 10) nilai Qn LST terbesar yakni 91,78 x $10^{3} \mathrm{~m} /$ tahun pada stasiun $11 \mathrm{ke}$ arah musim barat dan $-25,34 \times 10^{3} \mathrm{~m} /$ tahun pada stasiun $5 \mathrm{ke}$ arah musim timur.

Distribusi laju LST di sepanjang stasiun dari ketiga persamaan ditampilkan pada Gambar 4b. Sepanjang stasiun 1-5 dan 14 laju LST mengarah ke musim timur (1-5 ke barat daya, dan 14 ke barat laut), serta stasiun 6-13 mengarah ke musim barat (6 ke timur, 7-13 ke utara-timur laut). Pada gambar tersebut nampak bahwasanya pada stasiun 6-12 memiliki laju LST yang cenderung lebih cepat dibandingkan stasiun lainnya. Terlihat juga bila pada setiap persamaan menghasilkan laju LST yang tidak identik dengan persamaan lainnya.

Laju imbangan sedimen diperoleh dari selisih laju LST yang menuju dan meninggalkan segmen. Hasil $\mathrm{Q}$ imbangan sedimen ditunjukkan pada Gambar 4c. Imbangan sedimen di segmen 12 - 14 bernilai positif artinya segmen tersebut mendapat pasokan sedimen. Sedangkan $Q$ bernilai negatif pada segmen 1,4,6,10, dan 11. Artinya pada sedimen meninggalkan segmen tersebut dalam satuan $\mathrm{m}^{3}$ setiap tahunnya. Laju $\mathrm{Q}$ terbesar terdapat pada segmen 12 dan 13 sebesar 800 $\mathrm{x} 103 \mathrm{~m}^{3} /$ tahunnya yang menuju ke segmen tersebut. Sedangkan banyaknya sedimen yang meninggalkan segmen, terbesar pada segmen 10. Nilai tersebut berdasarkan persamaan LST milik Walton. Sedangkan untuk persamaan lainnya cenderung lebih kecil.

\section{Abrasi dan Akresi}

Analisis perubahan garis pantai menggunaan DSAS diperoleh daerah yang mengalami abrasi dan akresi. Fenomena tersebut dapat ditelaah lebih jauh dengan melihat proses-proses yang dapat mempengaruhi garis pantai. Sesuai dengan Triatmodjo (1999) bahwa proses pantai terdiri dari offshore-onshore dan longshore sediment transport. Berdasarkan hasil pada Gambar 5 didapatkan bahwa daerah abrasi yang terdapat pada segmen 1, 3, 6, 7, dan 8. Sedangkan daerah yang mengalami akresi yakni segmen 5, 11-14, serta sebagian kecil 9 dan segmen 2 .

Segmen 1 berada di ekor pulau, menunjukkan bahwa garis pantai yang nampak sangat bervariasi dan berubah setiap waktunya. Imbangan sedimen
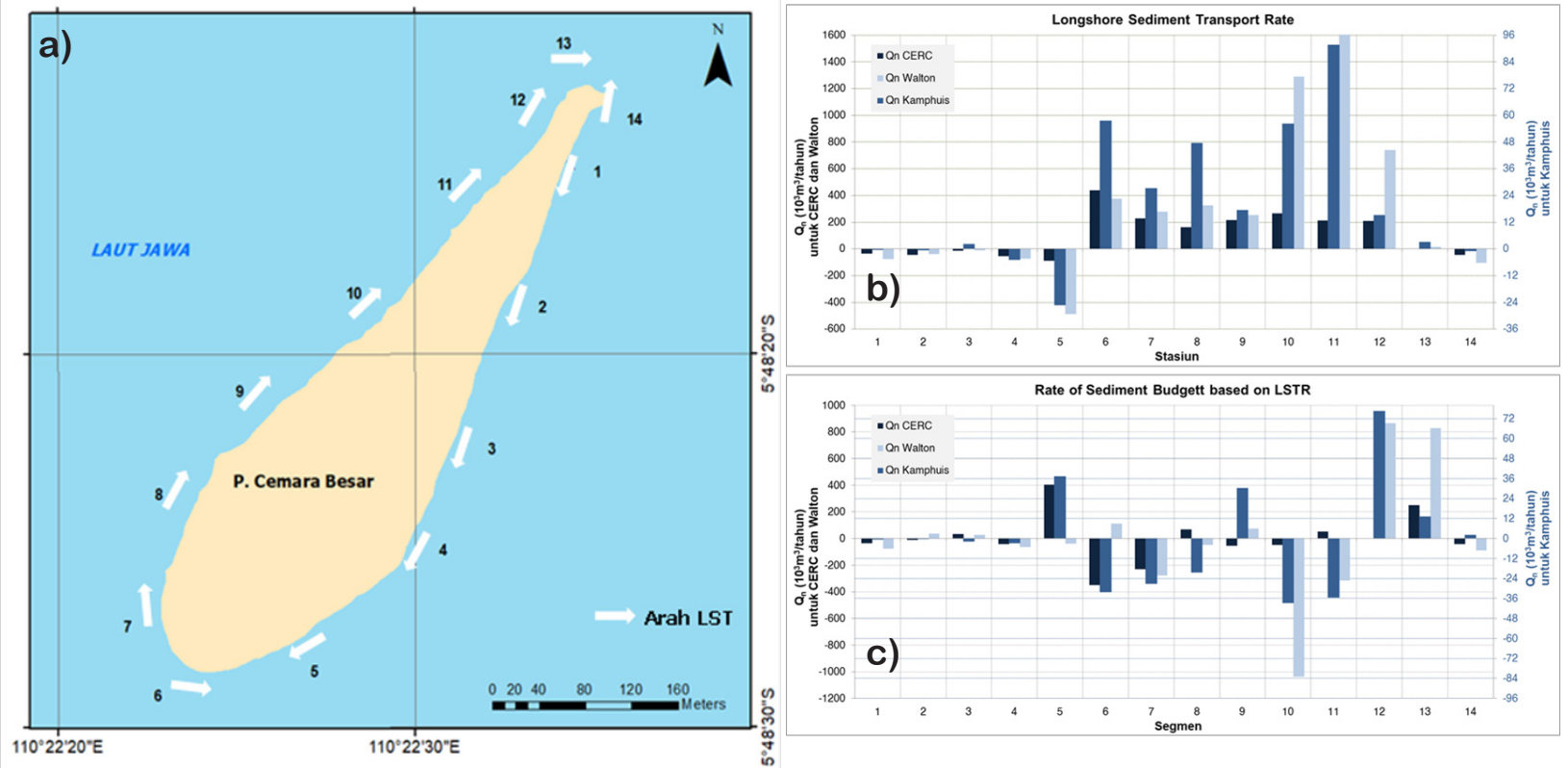

Gambar 4. Hasil Longshore Sediment Transport, a) arah LST; b) laju LST (LSTR); c) Laju Imbangan Sedimen (Q). 
berdasarkan laju LST menunjukan nilai negatif, artinya berdasarkan transport sedimen yang terjadi lebih banyak menghanyutkan sedimen dari segmen 1 ke segmen lainnya. Arah transport sedimen menuju ke segmen 2. Segmen 1 terjadi abrasi yang cenderung lebih jauh dan meluas dikarenakan tidak mendapat pasokan sedimen berdasarkan analisis LST. Kondisi oseanografi di segmen ini banyak dipengaruhi oleh penjalaran gelombang pada musim timur, dengan tinggi gelombang dibawah 1 meter dan mengarah ke barat daya. Kemungkinan pasokan sedimennya hanya sedikit berasal dari proses litoral lainnya dan kegiatan masyarakat dan wisatawan.

Kegiatan di pulau Cemara Besar mayoritas merupakan kegiatan wisata. Perahu-perahu pengantar wisatawan umumnya menurunkan penumpang di sekitar segmen 1 agak menjorok ke laut. Tentu aktivitas ini berpengaruh terhadap proses litoral dan menyebabkan abrasi yang cukup kuat di segmen 1. Aktivitas wisata pantai banyak dilakukan di sisi timur pulau, yakni sepanjang segmen 2 dan 3 .

Segmen 2 menunjukkan akresi sebagian kecil, dan abrasi yang meluas hingga segmen 3 . Ditandai dengan nilai laju perubahan garis pantai yang negatif dengan rata-rata $-1 \mathrm{~m} /$ tahun membuat segmen ini mengalami abrasi. Laju LST yang melewati segmen ini cenderung kecil dibanding segmen lainnya sehingga imbangan sedimen di segmen ini fluktuatif untuk setiap persamaan LST nya. Laju LST yang kecil didukung oleh pembangkitan transport sedimen yang sebagian besar mengandalkan penjalaran gelombang pada musim timur dengan tinggi gelombang yang rendah. Tentunya gelombang ini membangkitkan longshore current sebesar $0,78 \mathrm{~m} / \mathrm{s}$ sehingga laju LST di segmen ini mengarah ke segmen di sebelah selatannya yakni segmen 4 .

Pada segmen 4 ini secara rata-rata perubahan garis pantai menunjukkan abrasi. Dengan laju perubahan $0,17 \mathrm{~m} /$ tahun. Sehingga memang tampak tidak mengalami perubahan siginfikan, dan cenderung steady. Analisis LST menunjukkan sedimen bergerak ke arah segmen 5, akibat dari penjalaran gelombang dari arah timur laut. selain itu segmen ini mendapat pasokan sedimen dari segmen 3 , sehingga imbangan sedimen menunjukkan bahwa pada segmen ini mengalami abrasi dengan laju yang lebih kecil dibanding lainnya.

Segmen 5 terjadi akresi di sepanjang transeknya. Ditunjukkan pada Gambar 5 bahwa segmen 5 mengalami akresi. Hal ini dapat disebabkan akibat adanya pasokan sedimen dari segmen 4 dan 6 yang mengarah ke segmen 5 . Hal ini dikarenakan pada segmen 4 banyak dipengaruhi gelombang musim timur dan membangkitkan longshore current sebesar 2,38 $\mathrm{m} / \mathrm{s}$, sedangkan segmen 6 banyak dipengaruhi gelombang musim barat. Dengan demikian, segmen 5 sebagai pertemuan kedua LST tersebut menjadi deposit sedimen. Sedangkan untuk LST di segmen ini mengarah ke barat daya akibat lebih banyak pengaruh dari gelombang musim timur. Hal ini pun ditunjukkan oleh imbangan sedimen yang bernilai positif sebesar $400 \times 10^{3} \mathrm{~m}^{3} /$ tahunnya. Dengan demikian segmen 5 berpotensi memperluas daratan di pangkal pulau akibat LST yang terjadi, dan proses litoral lainnya.

Di lain sisi pangkal pulau, segmen 6 hingga 8 berdasarkan analisis DSAS menunjukan adanya abrasi dengan laju abrasinya mencapai $2,87 \mathrm{~m} /$ tahun. Hal ini juga diperkuat dengan nilai imbangan sedimen yang negatif untuk segmen 6 dan 7, sedangkan segmen 8 berbeda dari setiap persamaannya. Hal ini diakibatkan oleh penjalaran gelombang musim barat yang memiliki tinggi lebih dari 1,3 meter menghantam pantai dan menggerus sedimen di segmen tersebut. Gelombang tersebut membangkitkan longhshore current sebesar $4,19 \mathrm{~m} / \mathrm{s}$ yang membawa sedimen menuju ke segmen 9. Pada segmen 6 , sedimen terbawa ke segmen 5 . Sedangkan yang di segmen 7 terbawa ke segmen 8. Dengan demikian di ruang antara segmen 6 dan 7 tidak mendapat suplai sedimen dari segmen manapun. Selanjutnya sedimen dari segmen 7 terbawa ke segmen 8. Dikarenakan gelombang saat musim timur sedikit pengaruhnya pada segmen 8 ini, maka energi gelombang saat musim barat akan lebih banyak pengaruhnya dan cenderung menggerus sedimen. Dengan demikian imbangan sedimen di segmen 8

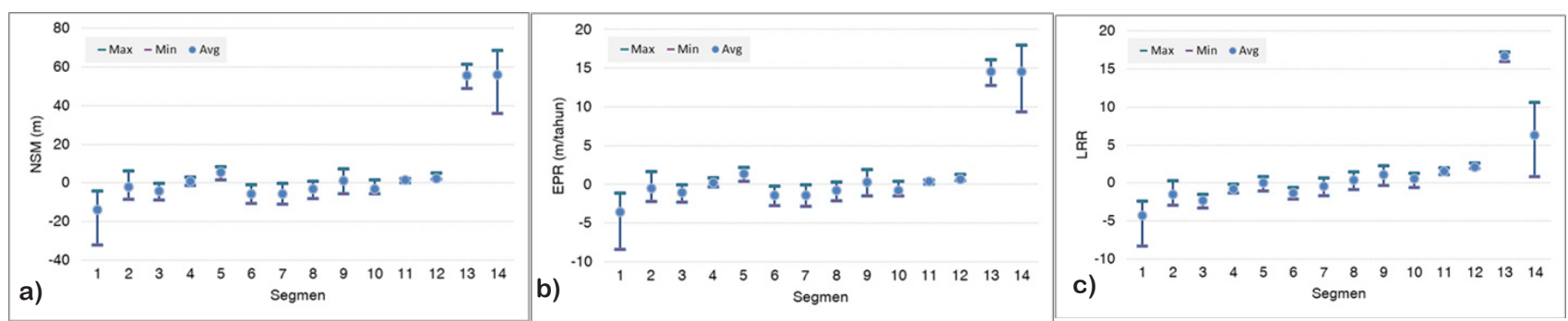

Gambar 5. Distribusi Data Segmen Hasil model DSAS a) Distribusi NSM; b) Distribusi EPR; c) Distribusi LRR. 
bernilai negatif.

Segmen 9 hingga segmen 12 berdarkan nilai LRR-nya menunjukkan adanya akresi. Namun tidak merata di seluruh segmen. Sebagian segmen 9 mengalami abrasi, dan hampir sepanjang segmen 10 mengalami abrasi. Laju abrasi di segmen 10 memang bernilai kecil, sekitar 0,78 m/tahun. Sedangkan untuk segmen 11 dan 12 ketiga metode DSAS seperti pada Gambar 5a-5c menunjukkan terjadi akresi. Dengan nilai laju perubahan rata-rata sebesar 0,3 hingga 0,6 $\mathrm{m} /$ tahun. Sepanjang segmen 9-12 banyak dipengaruhi oleh gelombang pada musim barat, dikarenakan berhadapan langsung dengan penjalaran gelombang dengan tinggi lebih dari 1,3 meter. Energi flux yang diterima oleh pantai menjadi besar dan membangkitkan longshore current dan LST. Longshore current musim barat pada segmen 11 menjadi yang tertinggi yakni sebesar $6,6 \mathrm{~m} / \mathrm{s}$. Sehingga pada Gambar $5 \mathrm{~b}$ laju LST di sepanjang segmen ini sangat besar terutama segmen 10 dan 11. Laju LST ini berpengaruh terhadap imbangan sedimen yang terjadi. Di sepanjang segmen ini, sedimen yang didapat berasal dari segmen di sebelah barat daya-nya. Dengan perhitungan sourcessink maka imbangan sedimen segmen ini memiliki nilai yang bervariasi untuk ketiga persamaan LST di sepanjang segmen. Hanya di segmen 10, hasil perhitungan dari ketiga persamaan menunjukkan abrasi.

Segmen yang mengalami akresi terbesar yakni segmen 13 dan 14. Segmen ini memiliki laju perubahan dan nilai regresi yang tinggi menunjukkan akresi yang tinggi. Artinya, garis pantai sepanjang tahun 20162020 konsisten bergerak maju menjauhi garis pantai terlama. Seperti ditunjukkan Gambar 5 a segmen ini terjadi perubahan posisi garis pantai sepanjang 55,9 meter dari garis pantai awal tahun 2016. Selain itu pada segmen ini menyumbang luasan akresi terbesar di sepanjang pantai. Akresi yang besar dan cepat ini dipengaruhi oleh kondisi gelombang dan geomorfologi pantainya. Pada segmen 13 terdapat longhsore current sebesar 4,6 m/s yang bergerak ke arah utara. Karena terletak di ekor pulau, maka ruas pantai di segmen 13 dan 14 terekspos dengan gelombang dari musim barat dan timur. Arah penjalaran gelombang menuju timur laut pada musim barat dan menuju barat daya pada musim timur. Segmen ini seperti menjadi titik temu LST dari segmen sekitarnya.

Segmen 13 sangat dipengaruhi oleh LST dari segmen 12, dengan laju LST yang cukup tinggi. sedangkan segmen 14 mendapat pasokan sedimen dari segmen 13 dan segmen 1. Laju LST segmen 13 menjadi laju terkecil disepanjang cemara besar, yang hanya berkisar $3,5 \times 10^{3} \mathrm{~m}^{3} /$ tahun saja. Sehingga memang banyaknya suplai yang diterima dari 12 menetap di segmen 13. Imbangan sedimen juga menunjukan nilai yang tinggi untuk segmen 13. Sedangkan segmen 14 imbangan sedimen bernilai kecil, berbanding terbalik dengan kondisi akresi yang kuat. Hal ini dapat diakibatkan karena laju LST dan transek model DSAS tidak berada di satu lokasi presisi yang sama. Sehingga imbangan sediman di stasiun 14 kecil namun banyak mengarah ke sel diantara 13 dan 14.

\section{Korelasi LST dengan Perubahan Garis Pantai}

Abrasi dan akresi secara spasial dapat ditunjukkan melalui analisis citra dan bantuan DSAS. Sedangkan abrasi dan akresi berdasarkan volume sedimen dapat dilakukan dengan 3 cara menurut Triatmodjo (1999), yang salah satunya menggunakan persamaan empiris. Sehingga dengan asumsi transport sedimen di zona litoral merupakan proses dan analisis spasial sebagai hasil tentu dapat dikaji korelasi dan keterkaitan antara 2 variabel tersebut.

Untuk menganalisis ini perlu mempertimbangkan proses-proses yang bekerja di zona litoral. Besaran yang mampu mewakili untuk analisis abrasi akresi adalah imbangan sedimen. Seperti disebutkan CERC, 1984 dan Bird, 2011 bahwa imbangan sedimen dipengaruhi oleh sources dan sink, dimaka sources terdiri dari LST in, onsore-offshore in, erosi dari darat, debit sungai dan beach nourishment. Sedangkan sink terdiri dari LST out, onshore-offshore out, transport ke inlet dan pengambilan pasir.

Analisis regresi linier menunjukan nilai keterkaitan yang rendah, ditunjukkan oleh kofisien determinasi sebesar 0,1178; 0,03375; dan 0,1383 untuk imbangan sedimen berdasarkan persamaan LST CERC pada Gambar 6a, Kamphuis pada Gambar 6b, dan Walton pada Gambar 6c terhadap nilai rata-rata laju perubahan garis pantai berdasarkan metode EPR. Dengan demikian laju LST yang berpengaruh terhadap laju perubahan garis pantai terbaik yakni persamaan walton sebesar $13,83 \%$.

Koefisien determinasi tersebut menunjukan pengaruh variabel imbangan sedimen yang hanya berdasarkan LST terhadap laju perubahan garis pantai sebesar $13,83 \%$. Sedangkaan sisanya sebesar $86,17 \%$ dipengaruhi oleh variabel lainnya yang tidak diteliti dalam penelitian ini.

Berdasarkan komponen penyusun persamaannya, pada persamaan LST Walton terdapat komponen longshore current, koefisien friksi dan lebar surf-zone yang tidak terdapat di persamaan lainnya. Dikarenakan kondisi pulau yang berhadapan langsung dengan gelombang sepanjang tahun, dengan kondisi tertentu membangkitkan longshore current di sepanjang pantai. Longshore current bernilai tinggi terutama di segmen 13 yang mencapai $4,6 \mathrm{~m} / \mathrm{s}$. Hal ini menjadi faktor utama 

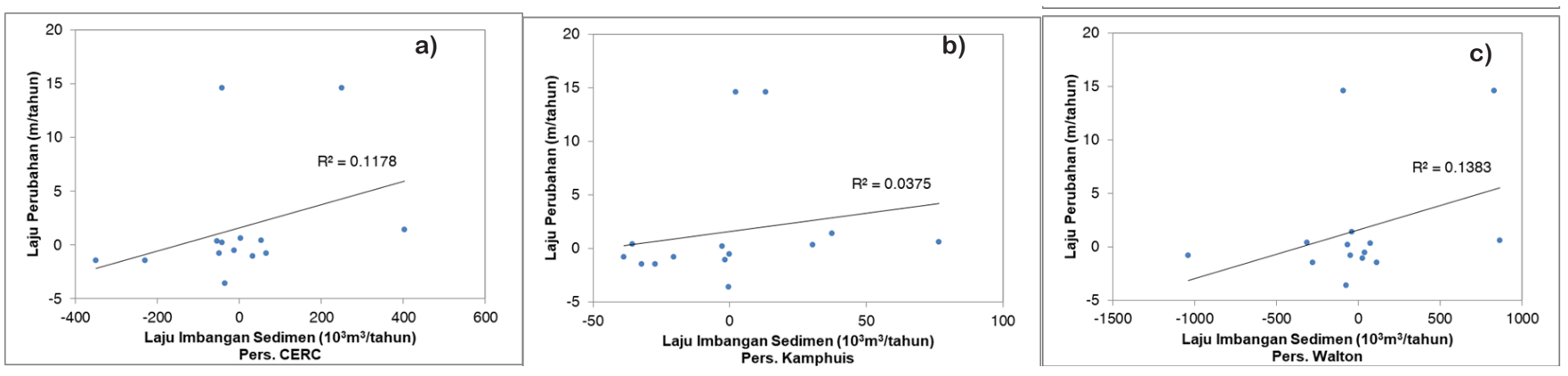

Gambar 6. Analisis Regression Linear Q imbangan sedimen (a) Persamaan CERC; b) Persamaan Kampuis; c) Persamaan Walton) vs Laju Perubahan Garis Pantai (EPR).

sebagai pembawa sedimen pada proses laju LST.

Melihat geomorfologi pantai Pulau Cemara Besar dan pemanfaatannya sebagai lokasi wisata di Karimunjawa maka proses litoral yang bekerja di sepanjang pantai yakni berupa LST, onshore-offshore sediment transport, transport sedimen oleh angin, dan aktivitas wisatawan. Tentunya semua komponen tersebut berpengaruh terhadap imbangan sedimen. Sehingga perubahan garis pantai di Pulau Cemara Besar dipengaruhi oleh komponen-komponen tersebut. Dalam hal ini variabel LST memiliki pengaruh sebesar $13,83 \%$ terhadap perubahan garis pantai yang terjadi di sepanjang pantai Pulau Cemara Besar.

\section{KESIMPULAN}

LST dan analisis perubahan garis pantai menunjukan adanya abrasi dan akresi di sepanjang pantai dengan abrasi kuat di daerah timur ekor pulau dan sisi selatan dan barat pangkal pulau, serta akresi kuat di utara ekor pulau dan sisi timur pangkal pulau. Perubahan garis pantai dipengaruhi oleh banyak komponen yang bekerja di litoral zone, salah satunya adalah Longshore Sediment Transport. Laju LST sebagai salah satu komponen imbangan sedimen memiliki pengaruh sebesar $13,83 \%$ terhadap perubahan garis pantai Pulau Cemara Besar.

Penelitian ini dapat dikembangkan lebih jauh dengan melakukan pengukuran langsung debit sedimen di sepanjang pantai pada kurun waktu tertentu sebagai pembanding dengan analisis persamaan empiris dengan kurun waktu yang lebih lama. Selain itu, dapat pula ditambahkan kajian mengenai proses litoral lainnya dan model numerik parameter oseanografi untuk mendukung pemenuhan pustaka penyusunan rencana ekowisata bahari di Cemara Besar.

Hasil penelitian ini dimanfaatkan untuk penentuan lokasi infrastuktur pendukung kegiatan ekowisata bahari di Pulau Cemara Besar. Infrastukutur yang dimaksud berupa anjungan sandar kapal, infrastuktur dasar, dan infrastuktur wisata. Pada dasarnya pembangunan infrastruktur diharapkan dapat bertahan dalam jangka waktu yang lama. Sehingga lokasi yang rentan terkena abrasi tentu tidak direkomendasikan, ataupun dapat dilakukan perlakuan khusus untuk merekayasa proses litoral di Pulau Cemara Besar.

\section{PERSANTUNAN}

Ucapan terimakasih kami sampaikan kepada Kepala Departemen Oseanografi dan Kepala Pusat Riset Kelautan yang telah memberi dukungan atas penelitian ini. Kontributor Utama artikel ini adalan Yulius dan Nur Kholik Kurniana Putra.

\section{DAFTAR PUSTAKA}

Aedla, R., Dwarakish, G.S., \& Reddy, D.V. (2015). Automatic Shoreline Detection and Change DetectionAnalysis of Netravati-GurpurRivermouth Using Histogram Equalization and Adaptive Thresholding Techniques. Aquat. Procedia, 4:563-570.

Alesheikh, A.A., Ghorbanali, A., \& Nouri, N. (2007). Coastline Change Detection Using Remote Sensing. Int. J. Environ. Sci. Technol, 4(1), 61-66.

Beatley, T., Brower, D., \& Schwab, A.K. (2002). An Introduction to Coastal Zone Management. Island Press.

Bird, E.C.F. (2011). Coastal Geomorphology: An Introduction. John Wiley \& Sons.

Boak, E.H., \& Turner. I.L. (2005). Shoreline Definition and Detection: A Review. J. Coast. Res, 688-703.

CEM, Usac. (2002). Coastal Engineering Manual.

CERC, S.P.M. (1984). Coastal Eng. Research Centre. US Army Corps Eng., Washington.

Chen, W.-W., \& Chang, H.-K, (2009). Estimation of Shoreline Position and Change from Satellite 
Images Considering Tidal Variation. Estuary. Coast. Shelf Sci, 84(1), 54-60.

Esmail, M., Mahmod, W.E., \& Fath, H. (2019). Assessment and Prediction of Shoreline Change Using Multi-Temporal Satellite Images and Statistics: Case Study of Damietta Coast, Egypt. Appl. Ocean Res, 82, 274-282.

Goswami, V., Samal, R.N., \& Choudhury, S.B. (2019). Monitoring of Chilika Lake Mouth Dynamics and Quantifying Rate of Shoreline Change Using $30 \mathrm{~m}$ Multi-Temporal Landsat Data. Data $\mathrm{Br}, 22$, 595-600.

Gibson, G.R. (2006). An Analysis of Shoreline Change at Little Lagoon, Alabama. Virginia Polytechnic Inst and State Univ Blacksburg Dept. of Geography.

Guariglia, A., Buonamassa, A., Losurdo, A., Saladino, R., Trivigno, M.L., Zaccagnino, A., \& Colangelo, A. (2006). A Multisource Approach for Coastline Mapping and Identification of Shoreline Changes. Ann. Geophys., 49(1).

Himmelstoss, E.A., Henderson, R.E., Kratzmann, M.G., \& Farris. A.S. (2018). Digital Shoreline Analysis System (DSAS) Version 5.0 User Guide. US Geological Survey.

Horikawa, K. (1988). Nearshore Dynamics and Coastal Processes: Theory, Measurement, and Predictive Models. University of Tokyo Press.

Kamphuis, J.W. (2003). Alongshore Transport Rate of Sand. In: Coast. Eng. 2002 Solving Coast. Conundrums. World Scientific, p. 2478-2490.

Longuet-Higgins, M.S. (1970). Longshore Currents Generated by Obliquely Incident Sea Waves: 1. J. Geophys. Res, 75(33), 6778-6789.

Ramdhan, M., Yulius., \& Putra, N.K.K. (2020). Shoreline Change Dynamics using Digital Shoreline Analysis in Cemara Besar Island. Jurnal Segara, 16(2), 105-114.

Resio, D.T., Bratos, S.M., \& Thompson, E.F. (2003). Meteorology and Wave Climate, Chapter II2. Coast. Eng. Manual. US Army Corps Eng. Washington. DC:72.

Salmon, C., Duvat, V.K.E., \& Laurent, V. (2019). Human- and Climate-Driven Shoreline Changes on a Remote Mountainous Tropical Pacific Island: Tubuai, French Polynesia. Anthropocene, 25:100191.
Shanas, P.R., \& Kumar, V.S. (2014). Coastal Processes and Longshore Sediment Transport along Kundapura Coast, Central West Coast of India. Geomorphology, 214, 436-451.

Triatmodjo, B. (1999). Teknik Pantai. Beta Offset, Yogyakarta, 397.

Umardiono, A. (2011). Pengembangan Obyek Wisata Taman Nasional Laut Kepulauan Karimunjawa. Surabaya Univ. Airlangga.

Tood, L., Walton, Jr ., \& Bruno, R.O. (1989). Longshore Transport at a Detached Breakwater, Phase II. J. Coast. Res. 5(4), 679-691.

Wicaksono, A., \& P. Wicaksono. 2019. Akurasi Geometri Garis Pantai Hasil Transformasi Indeks Air Pada Berbagai Penutup Lahan Di Kabupaten Jepara. Maj. Geogr. Indones, 33(1), 86-94.

Willmott, C.J., \& Matsuura, K. (2005). Advantages of the Mean Absolute Error (MAE) over the Root Mean Square Error (RMSE) in Assessing Average Model Performance. Clim. Res, 30(1), 79-82.

Yuliana, E. (2017). Pengelolaan Ekowisata Bahari di Kawasan Konservasi Perairan Taman Nasional Karimunjawa. In: Optimalisasi Peran Sains dan Teknologi untuk Mewujudkan Smart City. Universitas Terbuka, Tangerang Selatan, pp. 89116.

Yulianda, F. (2007). Ekowisata Bahari Sebagai Alternatif Pemanfaatan Sumberdaya Pesisir Berbasis Konservasi. In: Makal. Semin. Sains.

Yulius., Ramdhan, M., Rahmania, R., Kadarwati, U., Khairunnisa, T., Saepuloh, D., Subandrio, J., \& Tussadiah. A. (2018). Buku Panduan Ekowisata Bahari. IPB Press, Bogor. 95. 